\title{
Bánházi Emőke
}

\section{Vörösmarty dramaturgiája}

Vörösmarty Mihályt egész életében vonzotta a dráma és a színház világa. Azt, hogy mit gondolt a színházról, az Árpád ébredésében (1837) így fogalmazta meg:

Ez a világ kicsinyben...

...De itt igazság ül a trónuson,

$\mathrm{S}$ mit ember és sors véte zsarnokul

Az szent egyenlön visszatorlatik.

Széles körü drámairodalmi olvasottságra, drámaelméleti müveltségre tett szert; rendszeresen járt színházba, egyik legszorgalmasabb tagja volt a Magyar Tudós Társaság színügyi és drámaíró bizottságának.

Drámaírói tevékenysége már az 1820-as években kibontakozott, később megszólalt mint dramaturg is: drámákat bírált, 1837 és 1842 között rendszeresen beszámolt a Pesti Magyar Színház előadásairól, végül az Elméleti töredékekben foglalta össze nézeteit a drámaírás müfaji követelményeiről. ${ }^{1}$

Vörösmarty első drámáit, drámakezdeményeit az 1820-as években írta.

1820 és 1822 között a Perczel család börzsönyi birtokán házitanítóskodik, ahol alkalma van barátságot kötni a szomszédos Bonyhád községben élő Egyed Antallal és Teslér Lászlóval. Teslér László, aki maga is foglalkozott irodalommal, valamint egy drámát is írt, Vörösmarty figyelmét a drámaírás felé irányítja. Itt születnek első drámakísérletei, köztük a Salamon című történeti színmü. Első drámáin, drámakísérletein Kisfaludy hatása érezhetöo. ${ }^{2}$

Amíg Vörösmarty színre nem lépett, Kisfaludy drámái és vígjátékai jelentették a magyar drámairodalmat. (Katona Bánk bánja már 1815-re elkészült, de nem volt visszhangja, a korabeli kritika nem értékelte, nem is adták elö. Nem tudni, hogy milyen hatást fejtett volna ki Vörösmartyra, és az egész irodalomra ez a dráma, ha megírása után színre került volna.)

Az első magyar színésztársaság Pesten 1815-ben feloszlott. Egy új társulat alakult 1819-ben, a Német Színház falai között játszott és abban az évben 18 előadást tartottak. Ezek közül az egyik Kisfaludy Károly Tatárok Magyarországon címü darabja volt. Kisfaludy drámái a maguk idejében nagyon népszerüek voltak. Maga Kisfaludy is bevallotta, hogy drámáit egyelöre csak a gyors siker érdekében írja, valamint azért, hogy a közönséggel megszerettesse a színházat. Szerinte a publikum akárminek tapsol, ha a darabban győz a magyar. ${ }^{3}$ Ezekhez a művekhez képest valódi áttörést jelentettek Vörösmarty drámái, s a korabeli irodalomban az ő müvei képviselték a magyar dráma csúcsát.

\footnotetext{
${ }^{1}$ VÖM 14. 281.

${ }^{2}$ Gyulai Pál 1879. (2. kiadás), 33-44.

${ }^{3}$ Malonyay Dezső 1891. 11-15.
} 


\section{A fátyol titkai}

A fátyol titkai 1833-34 között íródott, a Vérnász befejezése (1833) után kezdte el Vörösmarty, s 1834. október 16-án már minden bizonnyal kész volt. (Erről tanúskodik az a kézirat, melyet Bajzának írt, miszerint a darabot hamarosan küldi az Aurorának. $)^{4}$

A darabot meghatározza Kisfaludy hatása, valamint Vörösmarty saját ifjúkori drámakísérleteinek tapasztalata. Ebben az időben (1833) több felhívás is érkezett eredeti magyar drámák megírására, melyeknek következtében Vörösmarty indíttatva érezte magát, hogy a vígjáték múfajában újat, az eddiginél jobbat alkosson. Forrásait a magyar irodalmi hagyományokból meríti, Kisfaludytól mintául veszi a Kérők (1817) és a Csalódások (1828) hangulatát, magyar eredetiségét, helyzetkomikumát megtoldva saját vígjátékkísérleteinek sikerültebb elemeivel, gazdagítva a spanyol és a shakespeare-i vígjáték klasszikus hagyományaival.

Tóth Dezső szerint $A$ fátyol titkai a magyar drámairodalom szükségleteinek tudatos számontartásával készült. ${ }^{5}$ Vörösmarty szerint ,,az újabb vígjátékokban általában kevés poézis van hasontalanul Shakespeare-éihez, s különösen a spanyolokéihoz, mely utóbbiakat egy vidám és boldog, de közönségesnél nemesb és magasb élet képeinek lehet mondani". ${ }^{6}$

$\mathrm{Az}$ akkor népszerü szalonvígjáték és társadalmi dráma hangneme idegen volt Vörösmarty számára; ö olyan vígjátékot akart írni, amely igazodik a mindennapi Pest életéhez és ugyanakkor költői is.

A vígjáték alapötlete és alakjai megtalálhatók ifjúkori kísérleteiben is. A három diák motívuma sem először fordul elő nála: megjelenik a Hajta és Idában, valamint Az elbúsult deákban is. ${ }^{7}$

Hajta és Ida címü darabjában (1822) a három diák neve - Bajnok, Fondor, Kába - szintén nevetséges, jellemző név, ugyanakkor itt is jelen van a városi környezet, és az ifjak leánykérőben vannak.

Az elbúsult deák (vagy Elkeseredett deák - 1824) három patvaristája: Korom Mátyás, Kétség és Rojtos. A darabot 1823-ban írta „patvarista és jurátusi” élményeiből (Gyulai Pál: Vörösmarty életrajza). A föszereplő Korom Mátyás egy fiatal özvegy ügyét vállalta fel, de meggondolatlanságot követett el és ezért elkeseredett. Két társa - Kétség és Rojtos - unszolására megfogadja, hogy ezután jókedvüen viseli sorsát („vígságot fogad”). Találkozót beszél meg társaival egy városszéli fogadóban, hogy aztán elbujdossék. Azok hamarább érnek oda és ízetlenül udvarolni kezdenek egy falusi jegyző lányának, Julisnak. Korom beleszeret Julisba, és együttérzően hallgatja panaszait.

Ezek után „Jókedv, ne hagyj el engemet!” felkiáltással búcsúzik és elbujdosik. A jelenetek során több alakot ölt, elöször garabonciás deák egy falu határában, majd csapszékben iddogáló parasztok álmélkodását váltja ki, végül udvarolni kezd

\footnotetext{
${ }^{4}$ VÖM 10. 463-464.

${ }^{5}$ Uo. 465.

${ }^{6}$ Uo. 1. és 56.

${ }^{7}$ Uo. 4. és 465.
} 
egyikük feleségének. Eközben érkezik Julis az apjával, egymásra ismernek Korommal, aki ezután örökre ott marad. ${ }^{8}$

Vörösmartynak továbbra is kedves lehetett ez a téma, 1837-ben is tervezett egy diákokról szóló darabot, mely témájában $A$ fátyol titkainak lett volna a folytatása. Az alapötlet megtalálható az Örök zsidó (vagy Ahasverus) drámaterv első változatának a kéziratában: ${ }^{9}$

„,(Színdarabnak: Tanulók búcsúkor fogadást tesznek, hogy tíz év múlva össze jőnek számot adni előmeneteik, szerencséjük, vagy bal eseteikről örvendeni, vagy segíteni amint körülményeik kívánandják.)"

A fátyol titkai három, „vidékről jött” ifja: Kacor, Guta, Rigó nevükkel is jellemzettek. Vörösmarty nem ad nekik egyéni vonásokat, inkább típusokat rajzol: a divatos „harisnyás majmot”, a magyarkodót, valamint a müveletlent. Akkor jellemzi őket a legtalálóbban, amikor a negyedik felvonásban hozzájuk nem illő szerepbe kényszerítik őket: a francia divatot követő Kacor jó magyarnak öltözik, a magyarkodó Rigót a legutolsó divat szerinti öltözetben jeleníti meg, a müveletlen Gutát pedig tudósként tünteti fel.

A darabban szereplö, férfira éhes vénlány, Katica típusát megtaláljuk Kisfaludynál is a Csalódások címü vígjátékban, Luca alakjában. A rokonságot az is igazolja, hogy a Vörösmarty-darab első változatában a vénlány neve még Luca volt, amit utólag azért változtatott meg, hogy a hasonlóság ne legyen annyira árulkodó. ${ }^{10}$

Bayer keményen bírálta a darabot, szerinte a három ifjú története „inkább ízetlen, mint komikus mese", viszont Katicát a magyar vígjátékok legsikerültebb vénlányának tartja. ${ }^{11}$

Hangai és Vilma a darab főszereplői, kapcsolatuk Vörösmarty ifjúkori szerelmi élményét idézi. Horváth János szerint 1840-ig Vörösmarty költészetén át-átsuhan Etelka emléke. ${ }^{12} \mathrm{~A}$ darab témájában lehet, hogy hat egykori szerelmi csalódása. 1832-ben Etelka kezét megkérte Vojnits Barnabás de Bajsa, szabadkai földbirtokos, az esküvőt Bonyhádon tartották meg 1833. augusztus 8-án. Ezt az eseményt Vörösmartynál érzelmi válság követi, az 1834-es év egyik legválságosabb időszaka lett: nem tudott írni.

Horváth János szerint a darabot összefogja Vilma üde, fiatal alakja. ${ }^{13} \mathrm{Ez}$ az alak felismerhető Vörösmarty több más (még költői) müvében is, Etelkától ihletve. Lényegében rokon a Csongor és Tünde Tündéjével, csak itt alakjába némi pajkosság, hamisság is vegyül.

Vörösmarty költészetét végigkíséri a hamis lány motívuma ( $A$ hamis leányka, Szebb az asszony, ha hamis, A csalfa lány).

\footnotetext{
${ }^{8}$ Horváth János 1969. 17-19.

${ }^{9}$ VÖM 10., 4 és 465.

${ }^{10}$ Uo. 487.

${ }^{11}$ Uo. 471-472.

${ }^{12}$ Uo. 464.

${ }^{13}$ Uo. 8 és 107.
} 
Hangai alakja némiképp a töprengő költőt idézi, Bayer szerint „unalmasságával gyötör”, ${ }_{14}$ a Ligetié pedig Széchenyit, aki elképzeléseivel akkor Vörösmarty példaképe volt.

A negyedik felvonásban Ligeti által megszólaltatja Széchenyit, s vele együtt a reformkor eszményeit.

A Lidi - Vilma komornája - és Vilma közötti viszony emlékeztet Tünde és Ilma viszonyára, a tündérvilág vetülete a városi életre.

A darab rendkívül korhü, említést nyernek benne viták, lapok, nevek, helyek, melyek a korabeli Pestet idézik. Kigúnyolja benne füzfapoéta ismerőseit, kik a Jelenkornak küldözgetik „,müveiket”. Szerepel benne a „kegyed” és „ön” megszólítások közötti vita (Vörösmarty az utóbbit részesítette elönyben, ezt a megszólítást Széchenyi indítványozta). ${ }^{15}$

A darabban élénken jelen van a Városliget, a városligeti hangulat, Vörösmarty két pozitív szereplöjét is e hellyel kapcsolatosan nevezte el: Ligeti és Hangai.

A szereplök nevei és az általuk betöltött szerep között kavarodás van, ugyanis Vörösmarty később megváltoztatta a nevekhez kötődő szerepeket, de a darabot nem igazította ehhez. Így Vilma Ligeti leányaként szerepel, míg a darabban „bátyám”-nak szólítja Ligetit, Ligeti Vilmát pedig húgának; Lidi Vilmának komornája, később csak egy szobalány (a viszony közöttük mégis ugyanolyan bizalmas); Katica elöször ,aggszüz”-ként szerepel, később Ligeti testvérnénje s így Vilma nagynénje, de a darabban továbbra is „,kedves szomszéd úr”-nak szólítja Ligetit. Az, hogy Katica kiléte megváltozott, a darab erkölcsi töltetét is megváltoztatja, hisz míg előbb Vilma csak egy szószátyár vénlánnyal üzött tréfát, utóbb saját nagynénjével bánt elég csúful, pedig az neki semmit sem vétett; az első változatban Kacor, Guta és Rigó vidékről jött ifjak, a harmadikban már „távolról jött ifjak”-ká válnak, pedig az első megnevezés sokkal találóbb.

Vörösmartynak ezt a darabját sokan és sokféleképpen bírálták. Gyulai szerint nem tiszta vígjáték, inkább a bohózathoz közelít. Szerinte az alapötlet Moreto Közönyt közönnyel (vagy Donna Diana) címü drámájának az alapötletéböl származik: „Moretónál egy leány megveti a szerelmet, és sohase akar férjhez menni. Vörösmartynál egy férfi gyűlöli a szerelmet, és szintén sohase akar nősülni. Ott Dianát meghódítja Carlos, közönyt tettetve, itt Hangait Vilma, ki öt egyszersmind büntetni akarja." ${ }^{16}$ Toldy Ferenc kifogásolja, és egyszersmind hihetetlennek is tartja azt, hogy Hangai a lefátyolozott alakban nem ismeri fel Vilmát alakjáról és hangjáról. Erkölcsileg elítélendőnek tartja azt, hogy Vilma mint úrilány éjnek idején szobalányával sétálgat az utcán, ott idegen úrral szóba elegyedik, azt, hogy a városligeti bokrokban bujkálnak, hogy idegen urak beszédét kihallgatják stb. Ertékeli a darab nyelvét. Úgy tudja, hogy a darabot hiányosságai miatt egyszer sem adták elő (ezt

\footnotetext{
${ }^{14}$ Uo. 107.

${ }^{15}$ Uo. 4 és 494.

${ }^{16}$ Uo. 2, 214.
} 
rosszul tudja), ${ }^{17}$ de (szerinte) ha előadták volna, akkor sem maradhatott volna meg a színpadon. ${ }^{18}$

Amint már említettem, Bayer keményen bírálta a darabot, Szász Károly már méltányosabb, Vértesy még inkább: azt állítja, hogy Vörösmarty kortársai is naiv eszközökkel dolgoztak, de az ő költészete és humora nélkül; Hangai és Vilma párbeszédeiben sok a szikrázó szellem, ügyes fordulat, finoman élcezett beszéd. ${ }^{19}$

Malonyay Dezső szerint „Vörösmarty nem volt igazi drámaíró. Ami eposait nyelv, kidolgozás és tartalom tekintetében értékessé teszi, az volt a drámában legszembeötlőbb gyöngesége.” ${ }^{20}$ Szerinte Vörösmarty drámáinak szerkezete aránytalan, a cselekmény nem egységes, nem következetes és többnyire fölösleges epizódokkal terhelt, ${ }^{21}$ nem tudja kiaknázni a helyzeteket, valamint ,a természetszerüleg kínálkozó összeütközéseket elejti s váratlan, természetellenes, sokszor erőtlen fordulatokkal találkozunk". 22 (Ez utóbbi tényt azzal magyarázza, hogy Vörösmartynak rossz volt a megfigyelőképessége.) Alakjai nem jellemzőek sem tetteikben, sem beszédmódjukban; nem a saját érzéseiket fejezik ki (nincsenek egyéni érzéseik), hanem a költő rajongása szólal meg ajkaikon - akárcsak Schillernél. Mindkettőjükben közös az, hogy nagyon jól festik meg a gonoszt. ${ }^{23}$ Szerinte $A$ fátyol titkai ,nem egyéb, mint részben a költő fantasiájának önkényes szüleménye, részben pedig a Moreto Donna Dianájának halvány utánzata". Egyedül a nyelv erejét méltatja a darabból. ${ }^{24}$

Weber Arthur Shakespeare hatását mutatja ki, közös elemeket talál A fátyol titkaiban és a Felsült szerelmesekben, a Sok hühó semmiértben, a Vizkeresztben. ${ }^{25}$ A dráma vegyes: prózai és költői elemek egyszerre vannak jelen benne, köznapi dolgokról prózában, emelkedettebb témákról versben beszélnek. Hangai és Vilma állandóan versben beszélnek, ez szintén Shakespeare-hatás. Vörösmarty írja az Elméleti töredékekben: „A drámai személyek különféle characterei különböző nyelvet is kívánnak." "26 Szerinte a darab „olyan, mint egy mozaik, több helyről vett kövekből látszik összerakottnak ... nagyon valószínü, hogy a Shakespeare-darabok hatása tárgyi szempontból csak önkéntelen, nem szándékolt". ${ }^{27}$ Abban követte el a hibát,

${ }^{17}$ Toldy Ferenc téved, a darabot többször is elöadták: Debrecen, 1836. márc. 27., Debrecen, 1836. ápr. 24., Rév-Komárom, 1837. júl. 23., Debrecen, 1838. nyárhó 28., Székesfehérvár, 1844. márc., Pest, Nemzeti Színház, 1844. május 9. Lm. i. m. 4, 481.

${ }^{18}$ VÖM 10. 4 és 469-470.

${ }^{19}$ Uo. 8, 108.

${ }^{20}$ Uo. 3, 11 .

${ }^{21}$ Lm. uo. $13-15$.

${ }^{22}$ Uo. 14.

${ }^{23}$ Lm. uo. 14-18.

${ }^{24}$ Uo. 19.

${ }^{25}$ Weber Arthur: Shakespeare hatása a vigjátékíró Vörösmartyra. Különnyomat a „Magyar Shakespeare-Tár" 1911. év 3. füzetéböl, Franklin-Társulat nyomdája, Budapest 1911.

${ }^{26}$ VÖM 10. 14, 43.

${ }^{27}$ Uo. 25,34 . 
hogy „a XIX. század közepén egy Shakespeare-féle darabot írt, a nagy angol inspirátiója alatt, de annak jó oldalai és előnyei nélkül’" ${ }^{28}$

A darabnak minden fogyatékosságát megértjük, ha elolvassuk Vörösmarty vígjátékokra szabott követelményeit, melyek a Dramaturgiai lapokban jelentek meg:

„A víg színmü a hétköznapi élet apró bajai körül forog, s ennek hibáit róva, nevetséges oldalait kitüntetve, mulattat és tanít egyszersmind ... nem foglalkozik megrázó, nagy következetű cselekményekkel."29

Szerinte a tragédia célja az emberi erények és hibák küzdelméből származó bukás feltüntetése, a komédiáé az emberi gyarlóságok kudarcának a festése. A tragédia célját idealizálással, a komédia a valóság torzításával érheti el. A valódi vígjáték tehát nem az emberek tükörképét jeleníti meg, hanem kiemeli a nevetséges, torz oldalát, azt felnagyítja és visszatükrözi. A vígjáték nem embereket, hanem típusokat fest:

„... meglesi s elárulja a színes hálálkodót, az erényhazudót; megszégyeníti a gőgöst, hetvenkedőt, csúffá teszi az alacsony szenvedélyüt: az irígyet, fösvényt; kineveti az ügyetlent, a testiség rabjait: részeget, korhelyt s a könnyelmü pazart saját kezeikkel vereti meg ... individuumok helyett inkább fajt vagy nemet hoz a színre", a vígjátékban a szereplőket ,úgy lehet tekinteni, mint egy egész osztály képviselöjét., 30

Szerinte ,a nevetség a leghatalmasabb fegyver, hatalmasabb gyakran a pathosnál, mellynek ellenkezője". 31 Éppen ezért nem szabad (vagy nem szabad túlzottan) nevetségessé tenni a pozitív hősöket a negatív hősökkel szemben, mert ,itt is a költői igazságnak kell a fö elvnek lenni: különben a szín igen hamar ál tan, hamis morál terjesztője lesz". 32

A vígjáték és dráma célja között is különbség van, a dráma célja valamely magas eszme megérintése, ,a víg dráma személyei bizonyos anyagi jólét, vagy szellemi élmény után törekednek". ${ }^{3}$ Vörösmarty szerint a pozitív hősök kell hogy elérjék céljaikat: „midőn valamelly szerencsét (p. o. egy kellemes, szeretetre méltó leányt ...) balga, silány keblü csapodár elől, az okos, elmés, jeles ügyes ... nyeri meg, igen helyén van a dolog". ${ }^{44}$ Ennek vagyunk a tanúi $A$ fátyol titkaiban is, amikor Hangai elnyeri Vilmát (Vilma szerelmét) a három ifjú (Kacor, Rigó, Guta) elől.

Szerinte a jó vígjáték két fő részből: komoly és vidám részből áll. Vörösmarty szavaival: „,... vígjátékainknak többnyire van komoly része is "35, de ebben nem Kisfaludytól és Kotzebue-tól veszi a mintát, akik ezt a komoly részt az érzelgősség felé tolják ki, hanem Shakespeare-től, ahol ,a dráma komolyabb részei a tragoedia nyelvének s érzelmeinek bélyegét viselik ... Azonban vannak víg darabok, hol a ko-

\footnotetext{
${ }^{28}$ Uo. 35 .

${ }^{29}$ Uo. 14, 53-54.

${ }^{30}$ Uo. 54.

${ }^{31}$ Uo. 54.

${ }^{32}$ Uo. 54.

${ }^{33}$ Uo. 54 .

${ }^{34}$ Uo. 55 .

${ }^{35}$ Uo. 55 .
} 
moly szándék enyelgés, $\mathrm{s}$ öncsalás palástjába burkozik ... az ilyen müvet lehet a legtisztább vígjátéknak mondani." ${ }^{36}$

Tehát Vörösmarty célja az volt, hogy tiszta vígjátékot alkosson. Megteremti a komikus epizódot, valamint változtat az alaptörténet hangnemén is, keveri az érzelgőst a dévajjal. A komikus részt kibővíti, a föcselekménynél is terjedelmesebb komikus epizódot csatol a fötörténethez, de közben a kettőnek semmi összeköttetése nincs egymással. Ez a darab vígjátéki jellegét emeli, viszont ezzel a módszerrel sokkal terjedelmesebbé és nehézkesebbé válik. ${ }^{37} \mathrm{Ez}$ az oka annak, hogy $A$ fátyol titkai ritkán szerepelt a színpadon. Görgey 1968-ban átírta, lerövidítette Handabasa avagy A fátyol titkai címen, megfüszerezte a 60 -as évek zenéjével s egyúttal szellemével, ezáltal korszerüvé s népszerübbé tette. ${ }^{38}$

Ez a fajta vígjáték tehát három elemből tevődik össze: az alaptörténetből (amely komoly), a járulék-cselekményből (amely komikus és a darab bohózatjellegét növeli), valamint a gúnyolódó szójátékokból és beszédstílusból. ${ }^{39}$

${ }^{36}$ VÖM 10. 14 és 55.

${ }^{37}$ Uo. 25.

${ }^{38}$ Uo. 4, 479-481.

${ }^{39}$ Uo. $25,5-17$. 


\section{Vers, helyzet, hatás}


